\title{
色覚異常 5 症例の治療報告 5 Cases Report of Color Blindness
}

後 藤 公 哉*

\section{はじめに}

色盲治療は過去に中谷義雄1ををはじめ、東京 医科大学眼科教室の関亮、元日本良導絡自律 神経学会会長、野津謙がイタリアローマ国際 学校保険学会で報告、マスコミにも報道され るなど、幾多の報告がある。当院に来院した 色覚異常の良導絡治療症例を報告する。

\section{治療方法}

本治法として全良導絡調整療法 $\mathrm{III} \sim \mathrm{V}$ 型 ${ }^{2}$ を 使用した。標治法として中谷A B 点. $\mathrm{H} 6-4$ (合 谷)、F6-44 (巨髎)、F5-8 (光明)、F2-2 (行 間）を使用した。全良導絡調整に 1 寸 6 分 5 番銊、子供には電気集毛針、顔面部置針には 1 寸 5 番鍼を使用した。刺激法は、電気銊法 (F R 鍼管使用、除極より200マイクロアンペ $P 7$ 秒通電)、低周波置針療法 $(3 \mathrm{~Hz} 、 15$ 分間 $)$ を使用した。また眼球を上下左右斜化動か す目の運動を指示した。

\section{中谷 $A B$ 点}

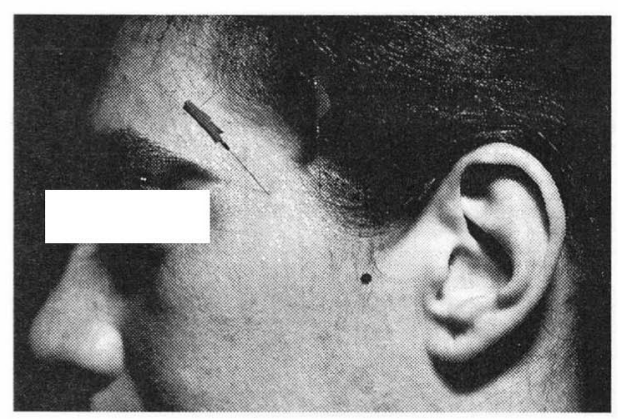

\section{結 果}

効果判定に良導絡チャートの治療前と治療 後の比較検討を行なった。色盲検査表（学校 用色覚異常検査表 ${ }^{3)}$ ・Uらがな色盲検查表 ${ }^{4)}$ 、 石原忍考案、12表、半田屋商店発刊）を使用 した。

色覚検査表の 1 表正読を 1 ポイントとして、 正読 8 ポイント有効とした。

5 症例中、 3 例がポイント 8 以上で有効、不 変 1 例、脱落 1 例であった。

\section{症例 1}

赵10才

既往歴：なし

現病歴：小学校で色弱と診断。治療法をしら ず、知人紹介来院。顔色蒼白、舌唇色薄人、 自汗、舌淡から気血両虚と思われる。 初診時良導絡チャート：F 2 (肝) F 4 (膀 胱） F 5 (胆) F 6 (胃) 興鹪、H 1 (肺) $\mathrm{H} 5$ (リンパ） F 1 (脾) 抑制が著明で、目 と関連の良導絡に異常があり、気血不和で目 の滋養が出来ないものと考えられる。色覚検 查表正読 1 ポイントであった。10表を 8 と読 み、12表を 1 と読むことから緑色弱と思われ る。

\footnotetext{
*後藤鍼炎整体療院 厂221-0076 横浜市神奈川区白幡町2-8 TEL 045(401) 3917 FAX 045(401) 7389 $\mathrm{E} \times$ ール
}

キーワード：直流電気鍼・中谷 $A \cdot B$ 点、 $F_{1}$ (脾良導絡 $) \cdot F_{6}($ 胃良導絡 $)$ 
初診時良導絡チャート

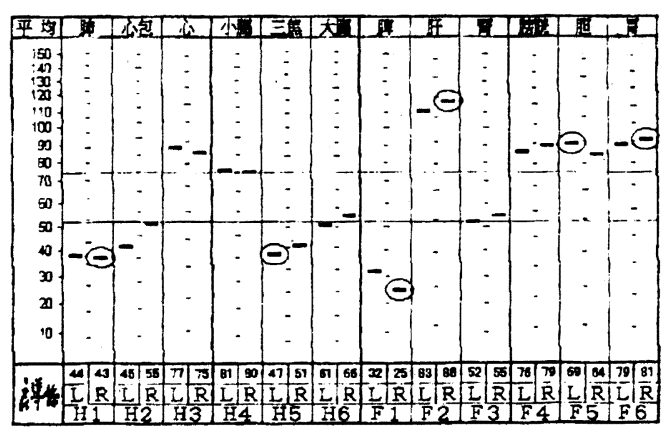

\section{7診時良導絡チャート}

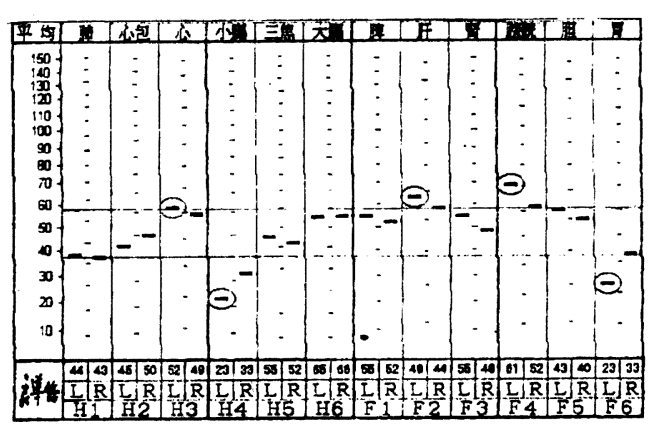

治療経過：1～9 診 : H M 17 (身柱)、H M6

(命門)、VM11（中脘）に電気集毛銊施術後、 中谷A B 点、H6-4 (合谷) に置鍼10分間。目 の運動を指示した。色覚検査表正読 1 から 3 ポイント。10 15診：HM17 (身柱)、HM6 (命門)、F 4-37 (肝俞)、F 4-35 (脾俞)、F 4-32（腎俞）に電気集毛鍼施術後、A B 点、 F 6-44 (巨髎)、H6-4 (合谷)、F 5-8 (光明)、 F 2-2 (行間) に低周波置鍼治療、3 Hz10分間。 10-12診では同上治療に A B 点に直流電気鍼 7 秒通電を行ない、学校用色覚検査表を覚えて しまう可能性を考えて色覚検査表ひらがな用 に変えて行なった、正読 3 ポイントであった。 16〜20診：HM17 (身柱)、HM6 (命門)、F 4-37 (肝俞)、F 4-35 (脾俞)、F 4-32 (腎俞)、 VM11（中脘）、F 4-59 (天柱)、F 5-25（風 池)、H M26 (百会)、A B 点に電気集毛鍼か ら直流電気鍼に変えて行なった、 $\mathrm{A} \mathrm{B}$ 点、 $\mathrm{F}$ 6-44 (巨髎)、H6-4（合谷）、F 5-8 (光明)、 F 2-2（行間）に低周波置鍼治療 $3 \mathrm{~Hz} 15$ 分間。 良導絡チャートバラツキF 1 (脾) F 2 (肝) が改善、色覚検査表正読初診時 1 ポイントか ら17診時10ポイントに改善した。

\section{Color Blindness Test Results 石原式学校用色賞検查表}

\begin{tabular}{|c|c|c|c|c|c|c|c|c|c|c|c|c|c|c|c|}
\hline 回 & 月日/正読 & & 25 & 2 & 5 & 8 & 3 & 9 & 6 & 4 & - & 58 & $\Omega$ & + & $\mathrm{Pt}$ \\
\hline 1 & 4 Aug. & $B$ & (2) & 7 & 9 & 5 & - & - & - & - & - & 8 & - & 1 & 1 \\
\hline 2 & 5 Aug. & A & Y & 7 & 9 & 5 & - & - & - & - & - & 8 & - & 1 & 1 \\
\hline 3 & 8 Aug. & $\mathrm{A}$ & 25 & 7 & 9 & 5 & - & - & - & - & - & 8 & 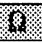 & 1 & 2 \\
\hline 4 & 15 Aug. & A & 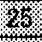 & 7 & 9 & 5 & - & - & - & - & - & 8 & - & 1 & 1 \\
\hline 5 & 18 Aug. & $\mathrm{A}$ & 藻 & 7 & 9 & 5 & - & - & - & - & - & 8 & 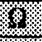 & 1.8. & 3 \\
\hline 6 & 21 Aug. & $\Lambda$ & 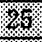 & 7 & 9 & 5 & - & - & - & - & - & 8 & 筮新 & r. & 3 \\
\hline 7 & 25 Aug. & A & 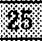 & 7 & - & 5 & - & - & - & - & - & - & - & . & 2 \\
\hline 8 & 29 Aug. & $\mathrm{A}$ & x. & 7 & - & 5 & - & - & - & - & - & - & \% & 1. & 3 \\
\hline 9 & 1 Sep. & A & 管. & 7 & 9 & 5 & - & - & - & 二 & - & - & 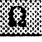 & 将. & 3 \\
\hline 10 & 4 Sep. & A & x. & 3 & 5 & 5 & - & - & - & - & - & - & - & X. & 2 \\
\hline 11 & 8 Sep. & A & 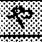 & 3 & 5 & $\hbar$ & さ & - & 二 & - & - & - & $x$ & $x$ & 3 \\
\hline 12 & 10 Sep. & $\mathrm{A}$ & . & 3 & 5 & 5 & さ & は & - & - & - & な & 约 & t. & 3 \\
\hline 13 & 15 Sep. & $\mathrm{A}$ & . & 7 & (13. & 5 & - & - & - & - & - & \% & 雬 & 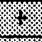 & 5 \\
\hline 14 & 19 Sep. & A & (2) & 7 & 6 & 5 & - & 9 & - & 4 & - & 88 & 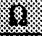 & (1) & 6 \\
\hline 15 & 22 Sep. & $A$ & 23. & 7 & 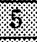 & 5 & - & 8 & - & - & - & 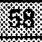 & 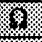 & (x) & 6 \\
\hline 16 & 23 Sep. & A. & (2) & 7 & 1. & 5 & - & 9 & - & - & - & s. & 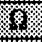 & 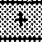 & 6 \\
\hline 17 & 29 Sep. & $A$ & 25 & 2 & 6 & 8 & (3) & 9 & - & . & - & 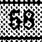 & 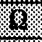 & 1 & 10 \\
\hline 18 & 6 Dec. & $\mathrm{A}$ & 26. & 2 & 6 & 8. & 8 & 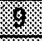 & - & . & - & ; & 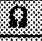 & . & 10 \\
\hline 19 & 10 Dec. & $\mathrm{A}$ & \% & 2. & 3 & 6. & 8 & 9 & - & . & - & 8 & \% & 18 & 10 \\
\hline 20 & 21 Dec. & A & 策㱍 & 2. & y. & 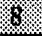 & 8 & 9 & 8 & 8 & 4 & 9 & (y) & r. & 10 \\
\hline
\end{tabular}


症例 2 万35

既往歴：なし

現病歴：小学校入学時色弱と診断。仕事に支 障はなかったが、趣味で魚の剝製を作成する のに、色付けが不鮮明で治療を希望、以前に 他クリニックにて低周波皮膚通電治療を受け たことがある。銊治療は初めてである。足腰 がだるく、不眠、口喉が渴き、舌紅から肝腎 陰虚と思われる。

初診時良導絡チャート：H 4 (小腸) F 2 (肝) 興奮、H 2 (血管) H 3 (心) F 3 (腎) 抑 制が著明であった。色覚検査表正読が 3 ポイ ントであった。 2 表を $7 、 8$ 表を 4 と読み、 10、12表を正読することから赤緑色弱と思わ れる。
初致時良算絡チャート

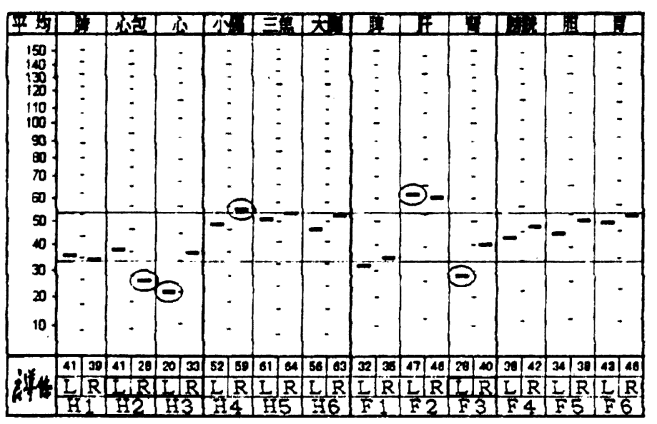

治療、経過：1３診、全良導絡調整III型。中 谷 A B 点、 $\mathrm{H} 6-4$ (合谷)、に低周波置針療法 $3 \mathrm{~Hz} 、 15$ 分間。目の運動を指示した。ポイン 卜 3 が 5 に改善したが、通院 2 時間と遠方の ため 3 回の治療で脱落したものと思われる。

\section{I - H Color Blindness Test Results 石原式学校用色觉検查表}

\begin{tabular}{|c|c|c|c|c|c|c|c|c|c|c|c|c|c|c|c|}
\hline & & & 1 & 2 & 3 & 4 & 5 & 6 & 7 & 8 & 9 & 10 & 11 & 12 & 計 \\
\hline 回 & 月日/正読 & & 25 & 2 & 5 & 8 & 3 & 9 & 6 & 4 & - & 58 & $\Omega$ & + & $\mathrm{Pt}$ \\
\hline \multirow[t]{2}{*}{1} & 8 Feb. & $B$ & 2 & 7 & - & - & - & - & - & 4 & - & 歽8 & - & . & 3 \\
\hline & & $\mathrm{A}$ & 25 & 7 & - & 8 & - & - & 4 & - & - & 2 & 9 & 将. & 5 \\
\hline \multirow[t]{2}{*}{2} & 15 Feb. & $B$ & & & & & & & & & & & & & \\
\hline & & $\mathrm{A}$ & 26 & 7 & - & 8 & - & - & - & - & - & 30 & 9 & 原. & 5 \\
\hline \multirow[t]{2}{*}{3} & 20 Feb. & $B$ & & & & & & & & & & & & & \\
\hline & & A & 26 & 7 & - & 13 & - & - & 6 & 4 & - & . & 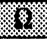 & . & 5 \\
\hline
\end{tabular}

$B=$ 治痖前 $A=$ 治療後

\section{症例 3 万人}

既往歴 : 副鼻腔炎、左顔面麻疸

現病歴：仕事がタクシー運転手で主訴は腰痛 と下肢が疲れつる、腰下肢は 5 回治療で改善。 色盲治療も希望。眩暈、耳鳴り、胸脇部痛、 不眠、舌紅から肝腎陰虚と思われる。

初診時良㦁絡チャート

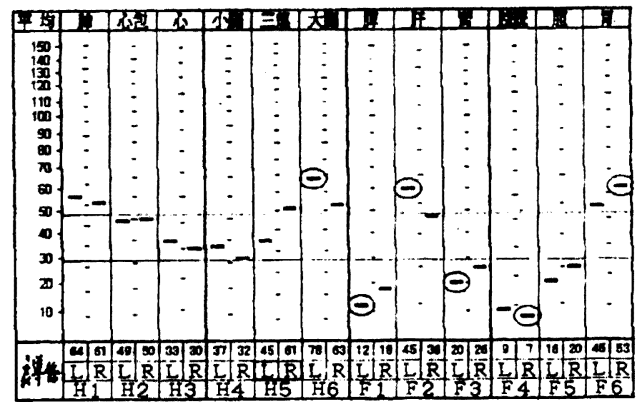

初診時良導絡チャート：H 6 (大腸) F2 (肝) F 6 （胃）興奮、F 1 (脾) F 3 (腎) F 4 (膀 胱）抑制が著明であった。色賞検査表正読が 1 ポイントであった。10表58を5、12表を読め ないことから緑色盲と思われる。

\section{1䩕時良胹絡チャート}

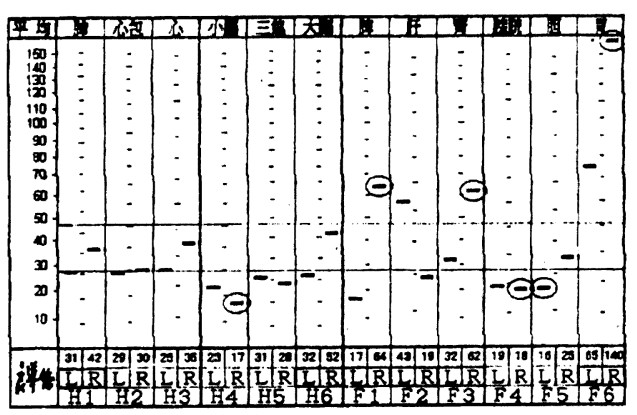


21祅時良導絡チャート

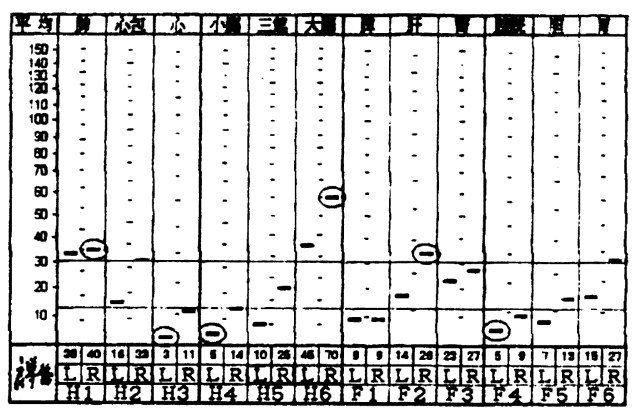

治療、経過：1１0診、全良導絡調整 V 型。中 谷A B 点、H6-4 (合谷)、F 6-44 (巨髎)、F 5-8 (光明)、F 2-2 (行間) に低周波置針療法 $3 \mathrm{~Hz} 、 10$ 分間。F 4-59 (天柱)、F 5-25 (風池)、 F 5-24（肩井）、F 4-37 (肝俞)、F 4-32（腎 俞）に置針10分間。 目の運動を指示。 色覚検査表正読 が1 ポイントから 3 ポイント。11〜 20診：頸肩こり、 耳鳴りがあり同治 療にH5-21 (耳門)、 H4-19 (聴宮)、F 5-42 (聴会)、H518 (㾔脈)、 $\mathrm{H} 5-17$

(㬾風)、H5-20（角 棌）に置鍼10分間。 良導絡チャートF 2 (肝) の改善は 見られなかった。 色覚検査表正読が 3 ポイント。21 30 診 : $11 〜 20$ 診と 同治療。良導絡千 ヤートのバラツキ F 1 (脾) F 2 (肝) は改善したが、色 覚検查表正読が 3 ポイント。

良導絡チャート 興抑は改善。治療
30䩕時良刑絡チャート

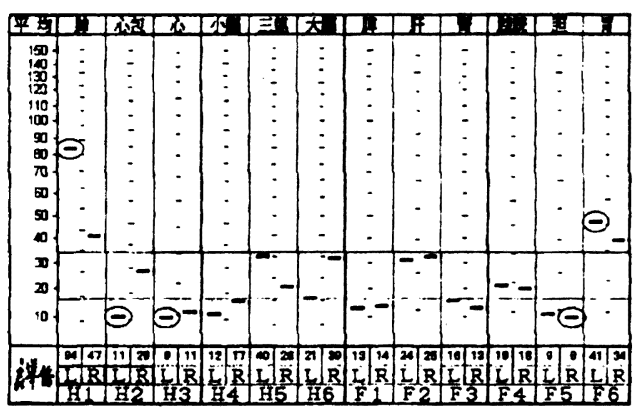

により景色に霞みや雲がかかっていたのが、 良く見えるようになり、世間が違って見える と感謝されたが、色覚検査表は 1 〜 ポイン トと改善は見られなかった。

\section{Color Blindness Test Results 石原式学校用色営検查表}

\begin{tabular}{|c|c|c|c|c|c|c|c|c|c|c|c|c|c|c|c|}
\hline 回 & 月日/正珫 & & 25 & 2 & 5 & 8 & 3 & 9 & 6 & 4 & - & 58 & $\Omega$ & + & $\mathrm{Pt}$ \\
\hline & ひながなる珫 & & p & 3 & あ & ま & き & ほ & 京 & い & 5 & †⿰ & い & に & \\
\hline 1 & 17 Aug. & B & 25 & - & - & 5 & - & - & - & - & - & 5 & - & - & 1 \\
\hline 2 & 22 Aug. & A & 23 & 7 & 8 & 8 & - & - & - & - & - & 56 & - & 1. & 2 \\
\hline 3 & 3 Sep. & $\mathrm{A}$ & 25 & 7 & - & 5 & - & - & - & - & - & 56 & 6 & t. & 3 \\
\hline 4 & 10 Sep. & A & 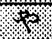 & 5 & $\hbar$ & 5 & さ & は & - & - & - & 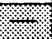 & - & - & 2 \\
\hline 5 & 19 Sep. & A & 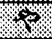 & 5 & $\hbar$ & 5 & さ & は & - & - & - & 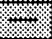 & - & - & 2 \\
\hline 6 & 24 Sep. & A & $25:$ & 7 & - & 5 & - & - & - & - & - & 16 & - & (1) & 2 \\
\hline 7 & 18 0ct. & 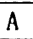 & 23 & 7 & - & 5 & - & - & - & - & - & 58 & - & t. & 3 \\
\hline 8 & 26 0ct. & $A$ & 23 & 7 & 3 & 5 & - & - & - & - & - & 383 & - & t) & 4 \\
\hline 9 & 2 Nov. & A & 282 & 7 & 3 & 5 & - & - & - & - & - & (58) & - & ? & 3 \\
\hline 10 & 9 Nov. & $\mathrm{A}$ & 235 & 7 & - & 5 & - & - & - & - & - & 68 & - & 18 & 3 \\
\hline 11 & 1 Dec. & A & 25 & 7 & 5 & 5 & - & - & - & - & - & 8 & - & 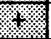 & 2 \\
\hline 12 & 3 Dec. & A & 25 & 7 & 3 & 5 & - & - & - & - & - & 58 & - & ? & 3 \\
\hline 13 & 16 Dec. & $A$ & 26 & 7 & - & 5 & - & - & - & - & - & \%58 & - & ?. & 3 \\
\hline 14 & 18 Dec. & A & 25 & 7 & - & 5 & - & - & - & - & - & 388 & - & 1. & 3 \\
\hline 15 & 19 Dec. & A & 23. & 7 & 1 & 5 & - & - & - & - & - & 588 & - & 3 & 3 \\
\hline 16 & 28 Dec. & A & 25 & 7 & - & 5 & - & - & - & - & - & 38 & - & ? & 3 \\
\hline 17 & 26 Jan. & A & 263. & 7 & 5 & 5 & - & - & - & - & - & 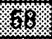 & - & 3 & 3 \\
\hline 18 & 22 Feb. & $A$ & 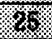 & 7 & 5 & 5 & - & - & - & - & - & 588 & - & 4 & 3 \\
\hline 19 & 4 Mar. & A & 25 & 7 & - & 5 & - & - & - & - & - & 38 & - & 1. & 3 \\
\hline 20 & 5 Mar. & A & 233. & 7 & - & 5 & - & - & - & - & - & 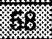 & - & ? & 3 \\
\hline 21 & 12 Mar. & A & 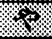 & 5 & 5 & よ & - & は & - & 5 & い & - & 13 & - & 2 \\
\hline 22 & 20 Mar. & A & 25 & 7 & 5 & 5 & - & - & - & - & - & 38 & - & ? & 3 \\
\hline 23 & 27 Dec. & A & 23 & 2 & - & 5 & - & - & - & - & - & 籍等 & - & 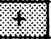 & 3 \\
\hline 24 & 8 Apr. & A & 23. & 7 & 5 & 5 & - & - & - & - & - & 58 & - & ? & 3 \\
\hline 25 & 18 May. & A & 25 & 7 & - & 5 & - & - & - & - & - & 38 & - & 1. & 3 \\
\hline 26 & 21 May. & A & 23. & 7 & - & 5 & - & - & - & - & - & 58 & - & , & 3 \\
\hline 27 & 25 May. & $\mathrm{A}$ & 26 & 7 & - & 5 & - & - & - & - & - & 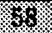 & - & I, & 3 \\
\hline 28 & $28 \mathrm{Jul}$. & A & (35 & 7 & - & 5 & - & - & - & - & - & 药药 & - & II) & 3 \\
\hline 29 & $30 \mathrm{Nov}$. & A & 26 & 7 & 5 & 5 & - & - & - & - & - & 58 & - & (T) & 3 \\
\hline 30 & 14 Dec. & A & 25 & 7 & - & 5 & - & - & - & - & - & 38 & - & II & 3 \\
\hline
\end{tabular}




\section{症例 4}

万 9 才 $^{51}$

既往暦：5 才時小児喘息

家族暦 : 特記すべきことなし

現病歴： 5 才時に喘息、鍼治療により完治し、 現在発作なし。学校検診で色盲と判明治療希 望。色覚検査表正読 3 ポイントで色弱と思わ る。

初診時良導絡チャート：F 2 (肝) F 4 (膀

胱) F 6 (胃) 興鹪、 H 4 (小腸) H 6 (大

腸）Ｆ１（脾）抑制、目と関係の深いF 2 (肝、

青） F 6 (胃、黄) の興奮と F 1 (脾、黄)

$\mathrm{H} 4$ (小腸、赤) $\mathrm{H} 6$ (大腸) 抑制が見られ 脾胃の化生が出来ず目を養えないものと思わ れる。初診時色賞異常検査表正読 3 ポイント であった。

初搒時良劕絡チャート

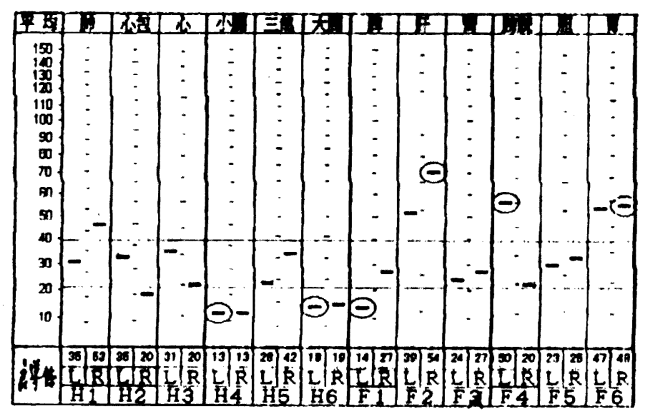

治療：1～ 5 診、HM17 (身柱)、HM6 (命 門)、VM11（中脘）に電気集毛鍼。A B 点、 H6-4 (合谷) 置鍼10分間。良導絡チャート： F 2 (肝) F 4 (膀胱) F 6 (胃) 興奮、 H 4 (小腸) H 6 (大腸) F 1 (脾) 抑制。 1 週間 3 回の治療で 3 から 6 ポイントに改善。 6 ～10診、HM17 (身柱)、HM6 (命門)、F 4-37 (肝俞)、 F 4-35 (脾俞)、F 4-32 (腎俞) に電気集毛鍼後、A B 点・H6-4 (合谷) に低 周波置鍼治療 $3 \mathrm{~Hz} 10$ 分。 7 診からの検査は数 字を覚えるのでUらがな用テストに变えて行 なった。ポイント 5 。11〜15診、HM17 (身 柱)、H M6 (命門)、F 4-37 (肝俞)、F 4-35

(脾俞)、F 4-32 (腎俞)、V M11 (中脘)、V M31（百会）に電気集毛鍼施術後、A B 点・ H6-4 (合谷) に低周波置鍼治療 $3 \mathrm{~Hz} 10$ 分。ポ
12診時良普絡チャート

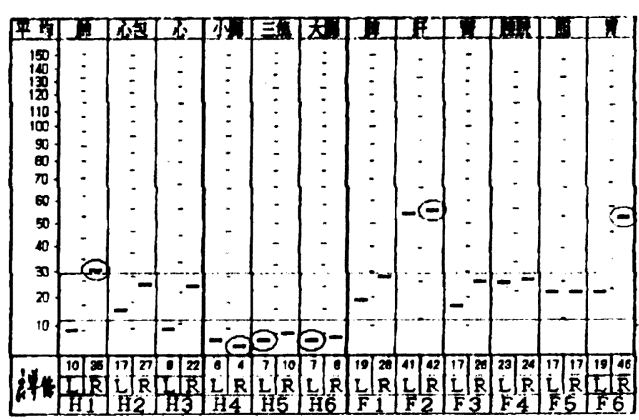

19診時良埒絡チャート

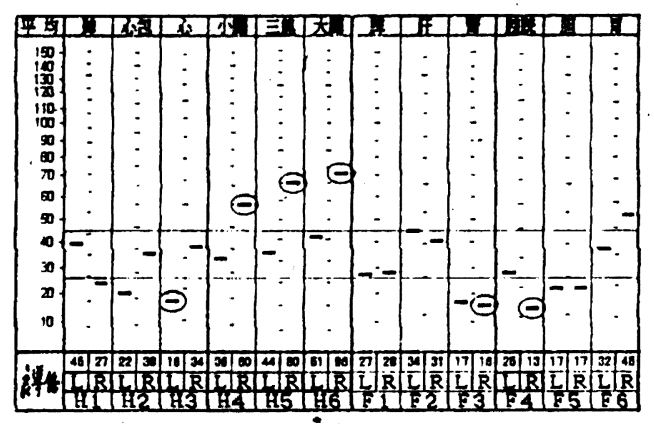

イント 7 。

16 19診：H M17 (身柱)、H H6 (命門)、F 4-37 (肝俞)、F 4-35 (脾俞)、F 4-32 (腎俞)、 V M11（中脘）、F 4-59 (天柱)、F 5-25（風 池)、V M31 (百会) に電気集毛鍼施術後、A $\mathrm{B}$ 点・ H6-4 (合谷) - F 5-88（光明） - F 228 (行間) に低周波置鍼治療 $3 \mathrm{~Hz} 15$ 分。 良導絡チャート：H 4 (小腸) H 5 (リンパ) H 6 (大腸) の 3 良導絡が右のみ興奮になっ た、F 3 (腎) F 4 (膀胱) 抑制。ポイント 8 。

全19回の治療でポイント 3 から 8 に解読出来 るようになった。7 7 月後バス旅行の為乗り 物酔いの治療で再診時、再度テストの結果ポ イント 8 を維持していた。 


\section{Color Blindness Test Results 石原式学校用色觉検查表}

\begin{tabular}{|c|c|c|c|c|c|c|c|c|c|c|c|c|c|c|c|}
\hline 回 & 月日/正珫 & & 25 & 2 & 5 & 8 & 3 & 9 & 6 & 4 & - & 58 & $\Omega$ & + & $\mathrm{Pt}$ \\
\hline 1 & 14 Aug. & $B$ & 2 & 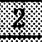 & 52 & 3 & 33 & 8 & - & - & (2) & 55 & 53 & 56 & 3 \\
\hline 2 & 15 Aug. & A & 筑筑 & 2 & 极 & 3 & - & 8 & - & 10 & r. & 56 & - & 54 & 4 \\
\hline 3 & 18 Aug. & B & 46 & 2 & (1). & 3 & - & 8 & - & - & . & 28 & 10 & - & 4 \\
\hline 4 & 20 Aug. & A & 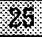 & 2 & 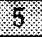 & 35 & 8 & 9. & - & - & . & 53 & 96 & - & 6 \\
\hline 5 & 21 Aug. & $\mathrm{A}$ & $2 / 3$ & $1 /$ & 5 & 8 & 3 & 9 & - & - & (-) & 53 & 96 & - & 7 \\
\hline 6 & 27 Aug. & $\mathrm{A}$ & 25 & 2 & 6 & 36 & 3 & 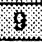 & - & - & . & 56 & 96 & 21 & 6 \\
\hline \multirow[t]{2}{*}{7} & 28 Aug. & B & x. & 5 & - & - & - & は & - & - & 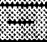 & - & 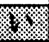 & - & 3 \\
\hline & & $A$ & 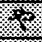 & 5 & - & L & - & は & - & - & . & - & - & (1) & 3 \\
\hline \multirow[t]{2}{*}{8} & 6 Sep. & B & w & 5 & - & よ & - & - & - & - & . & - & V. & - & 3 \\
\hline & & $\mathrm{A}$ & 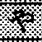 & 5 & - & よ & - & は & - & - & (1) & - & (2) & x. & 4 \\
\hline \multirow[t]{2}{*}{9} & 20 Sep. & B & . & s. & 5 & - & - & は & - & - & 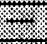 & - & V. & "W & 5 \\
\hline & & $\mathrm{A}$ & 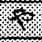 & 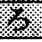 & 5 & L & - & は & - & - & 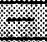 & - & 洨: & W. & 5 \\
\hline 10 & $40 \mathrm{ct}$. & $\mathrm{A}$ & 25 & 3 & (5. & 3 & 6 & 85 & - & - & X & 56 & - & 26 & 3 \\
\hline \multirow[t]{2}{*}{11} & $110 \mathrm{ct}$. & B & 25 & 2 & 6 & 5 & 3. & \% & - & - & ? & 56 & - & - & 5 \\
\hline & & $\mathrm{A}$ & 3 & 2 & 6 & . & 5 & 56 & - & 98 & 80 & 50 & 53 & - & 4 \\
\hline \multirow[t]{2}{*}{12} & 180 ct. & $B$ & 26 & 2 & 6 & 3 & 8 & 6 & - & - & 2. & 50 & 53 & 56 & 5 \\
\hline & & $\mathrm{A}$ & 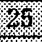 & 筑. & 筑. & 3 & 50 & 永 & - & 89 & য় & 56 & 66 & 51 & 5 \\
\hline \multirow[t]{2}{*}{13} & 8 Nov. & $B$ & 30 & 2. & . & 3 & 50 & (3) & - & - & r. & 59 & 58 & 50 & 5 \\
\hline & & A & 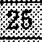 & 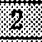 & 6 & 3 & 36 & 9 & - & - & . & 56 & 58 & 51 & 4 \\
\hline 14 & 15 Nov. & A & 25 & 2 & . & 3 & . & 9 & - & 51 & 1. & 59 & 56 & 21 & 6 \\
\hline 15 & 16 Nov. & $\mathrm{A}$ & $\frac{6}{25}$ & 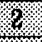 & 鉒 & 6 & 3 & 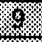 & 10 & - & . & 55 & - & 11 & 7 \\
\hline 16 & 23 Nov. & $\mathrm{A}$ & 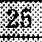 & 2 & 筷 & . & 3 & 9 & - & - & 0 & 56 & 16 & 11 & 6 \\
\hline \multirow[t]{2}{*}{17} & 29 Nov. & $B$ & \% & 曼. & 無 & 菜 & 带 & 9 & - & 19 & (2) & 50 & 13 & 11 & 7 \\
\hline & & $\mathrm{A}$ & 3 & 2 & $\sqrt{3}$ & 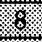 & 8 & 8. & - & 10 & . & 68 & 50 & 11 & 8 \\
\hline \multirow[t]{2}{*}{18} & 6 Dec. & $B$ & 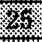 & 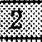 & 柆 & 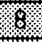 & 3 & \% & - & 10 & 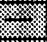 & 56 & 15 & 51 & 7 \\
\hline & & A & 2 & 2. & . & 桜 & 3 & (x) & - & 10 & . & (6) & 51 & 15 & 8 \\
\hline 19 & 13 Dec. & A & 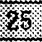 & 2 & 3 & 8 & 3 & 6. & - & 16 & . & 68 & - & 91 & 8 \\
\hline 20 & 28 Dec. & $B$ & 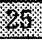 & 2 & 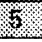 & 8 & 3 & 9 & 5 & - & . & s. & - & - & 8 \\
\hline
\end{tabular}

\section{$B=$ 治療前 $A=$ 治療後}

\section{症例 5 す 27 才}

既往歴：なし

現病歴：小学校四年生の時に色弱と診断され た。仕事がコンピューターグラフィクでいま までごまかして仕事をしていたが、緑が強く 赤が暗くなり色が不鮮明で困っている。鍼治 療を希望。仕事で長時間パソコン使用のため、

\section{初祅時良背絡チャート}

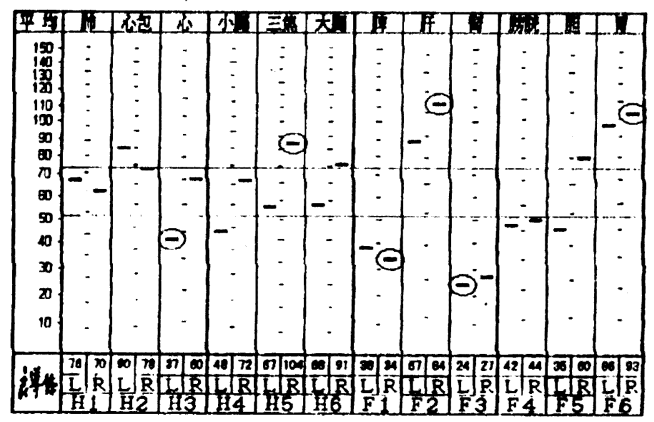

首肩がこり、目が疲れ、腰が重い、口渴、舌 紅から肝腎陰虚と思われる。

初診時良導絡チャート：H 5 (リンパ） F 2

(肝) F 6 (胃) 興鹤、 H 3 (心) F 1 (脾) F 3 (腎) 抑制が著明であった。色覚検査表 正読が 4 ポイントであった。 2 表を $7 、 8$ 表 を 4 と読むことから赤緑色弱と思われる。

9 祅時良導絡チャート

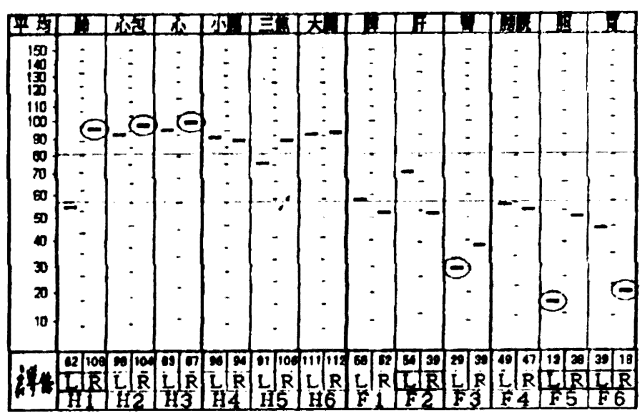


11診時良導絡チャート

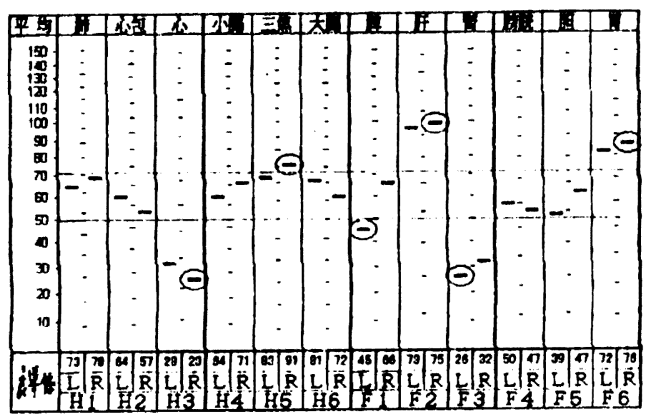

20診時良導絡チャート

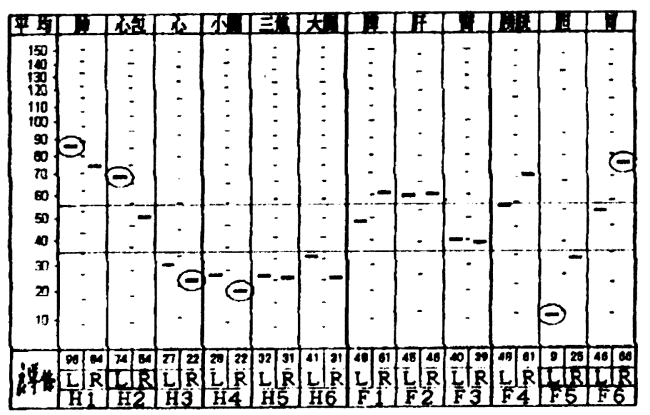

治療、経過：1～7 診、全良導絡調整III型。 中谷A B 点、H6-4 (合谷) に低周波置針療法
$3 \mathrm{~Hz} 、 15$ 分間。目の運動指示。色覚検査表正 読が 4 から 8 ポイントに改善。 8 〜 診 : 全 良導絡調整 V 型。中谷A B 点、 $\mathrm{H} 6-4$ (合谷)、 F 6-44（巨髎)、F 5-8 (光明)、F 2-2 (行間) に低周波置針㙩法 $3 \mathrm{~Hz} 、 15$ 分間。A B 点雀啄 10回。良導絡チャートのバラッキが改善、ひ らがな用色覚検査表で12ポイント (全部正読) の改善が得られた。10〜16診 : 頸肩がこり良 導絡チャートのバラツキが現れた。全良導絡 調整 V 型。中谷 $\mathrm{A} \mathrm{B}$ 点、 $\mathrm{H} 6-4$ (合谷)、F 644 (巨髎)、F 5-8 (光明)、F 2-2 (行間) に 低周波置針療法 $3 \mathrm{~Hz} 、 15$ 分間。F 4-59 (天柱)、 F 5-25（風池）、F 5-24（肩井）、F 4-37 (肝 俞)、F 4-32 (腎俞) に置針10分。色覚検査表 正読が10ポイント。17２0診：全良導絡調整 $\mathrm{V}$ 型。中谷 A B 点、F 4-59 (天柱)、F 5-24 (肩井)、F 4-37 (肝俞)、F 4-32 (腎俞) に 低周波置針療法 $3 \mathrm{~Hz} 、 15$ 分間。 $\mathrm{H} 6-4$ (合谷)、 F 5-8 (光明)、F 2-2 (行間) に置鍼10分。初 診時良導絡チャートF 2 (肝) 興F 3 (腎) 抑 が改善し、色覚検査表も 4 ポイントから 11 ポ イントに改善。色が鮮やかに見えるようにな つた。

Color Blindness Test Results 石原式学校用色觉検查表

\begin{tabular}{|c|c|c|c|c|c|c|c|c|c|c|c|c|c|c|c|}
\hline 回 & 月日/正読 & & 25 & 2 & 5 & 8 & 3 & 9 & 6 & 4 & - & 58 & $\Omega$ & + & $\mathrm{Pt}$ \\
\hline 1 & 2 Dec. & B & 26 & 7 & . & 6 & 5 & - & - & 6 & 4 & 96 & 0 & 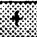 & 4 \\
\hline 2 & 9 Dec. & A & 23 & 7 & 6 & 8 & 8 & 4 & - & - & 4 & 6 & - & 椾 & 6 \\
\hline 3 & 16 Dec. & A & 管知 & 7 & 筑 & . & 㔍 & 9 & 6 & . & 4 & 等籍 & \% & 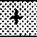 & 10 \\
\hline 4 & .23 Dec. & A & 6 & 7 & 6 & 8 & 3 & 9 & 4 & 6 & 4 & 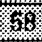 & 8 & 样样 & 8 \\
\hline 5 & 29 Dec. & A & 25 & 7 & 8 & 3 & 3 & 9 & 4 & 6 & 4 & 8 & 9 & $4.1 \%$ & 5 \\
\hline 6 & 6 Jan. & A & 26 & 7 & 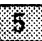 & 8 & 63) & 9 & 8 & $1 /$ & 4 & 68 & 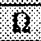 & (x. & 10 \\
\hline 7 & 13 Jan. & $\mathrm{A}$ & 28 & 7 & 8 & 5 & 8 & 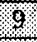 & 16 & 18 & 4 & 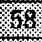 & 策 & 策济. & 8 \\
\hline 8 & 20 Jan. & $\mathrm{A}$ & . & . & 6. & 1 & (1) & s & . & . & . & \% & ( & 获 & 12 \\
\hline 9 & 27 Jan. & $A$ & 1) & \% & \%. & (1) & (⿳) & 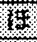 & \% & (1) & 6 & \% & 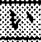 & 䒺 & 12 \\
\hline 10 & 2 Feb. & A & 25 & 7 & 样 & 8 & S & 等 6 & 4 & 6 & 4 & 动 & \% & 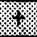 & 8 \\
\hline 11 & 17 Feb. & $\mathrm{A}$ & 2 & 7 & 6 & 9 & 3 & 9 & 8 & 1. & 4 & 36 & W & . & 10 \\
\hline 12 & 24 Feb. & $\mathrm{A}$ & 26 & 7 & ) & (2. & 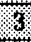 & 9 & 4 & 6 & 4 & 3. & 9 & w. & 8 \\
\hline 13 & 3 Mar. & $\mathrm{A}$ & 4 & 7 & 6 & . & I & 9 & . & , & 4 & क & $\%$ & 1. & 10 \\
\hline 14 & 10 Mar. & $A$ & 26 & 7 & 5 & 8 & 3 & 9 & 4 & 6 & 4 & 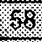 & 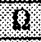 & 湆 & 8 \\
\hline 15 & 24 Mar. & $\mathrm{A}$ & 23 & 7 & 8 & 8 & 8 & 6 & 6 & 4. & 4 & 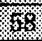 & 1 & . & 10 \\
\hline 16 & 1 Apr. & $\mathrm{A}$ & 25 & 7 & 3. & 8 & 3 & 9 & (1) & . & 4 & 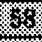 & 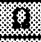 & . & 10 \\
\hline 17 & 7 Apr. & $\mathrm{A}$ & $2 \%$ & 7 & (1) & 6 & ( & 9 & 6 & w. & 4 & 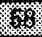 & \% & 麻. & 10 \\
\hline 18 & 15 Apr. & A & 86 & 8 & 6 & 8 & 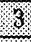 & 9 & 6 & . & 4 & 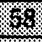 & 9 & r. & 11 \\
\hline 19 & 28 Apr. & A & 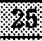 & 2 & (5. & 8 & 等 & 9 & 6 & 4 & 4 & 8 & $\%$ & 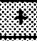 & 11 \\
\hline 20 & 5 May. & $\mathrm{A}$ & 2 & 2. & 8 & 8 & . & 9 & 6 & 4. & 4 & 48 & 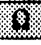 & 14 & 11 \\
\hline
\end{tabular}




\section{考 察}

中医学では、腎の精、肝の血、脾胃から化 成される気血は目を養い、視力を維持する。 肝腎陰虚、脾胃虚、目絡気血失和で目に影響 すると教えている ${ }^{6)}$ 。良導絡では、目全体はF 2 (肝、青)、上眼瞼はF 6 (胃、黄)、下眼瞼 はF 1 (脾、黄)、目の奥と瞳孔はF 3 (腎、黒)、 内側眼角は H3 (心、赤)、外側眼角はH4 (小 腸、赤) - F 4 (膀胱、黑) が目と関連する ${ }^{1)}$ 。 $\mathrm{H} 3$ （心） F1 (脾) は目を走行しないが、 $\mathrm{H}$ 4 (小腸) F 6 (胃) の表裏と関係があるもの と思われる。全症例とも初診時良導絡チャー トF 2 (肝) の興奮が著明であった。

中医に『肝は筋、疏泄 (通、散、気血の疏 通）を主り、目に開、華は爪にある』りとある。 目は肝の反応器官であり F 2 (肝) の調節が 大切であると考えられる。良導絡チャートで は、F2 (肝) の興奮、F 3 (腎) の抑制、F 1 (脾) の抑制、F6 (胃) 興奮の順に出現し た。F 2 (肝) F 3 (腎) の調整の他にF 1 (脾)

F 6 (胃) のアプローチが必要と思われる。 治療は20回が 1 クールで効果が上がらない 時は、時期を変えて治療する。低学年の治療 で効果が上がり、高学年になるほど効果が低 いし再発しやすいようである。

目の網膜の奥に錐体細胞（赤、緑、青の 3 種類）という色を感じる細胞があって、それ ぞれが未発達又は機能低下していることによ って、いろいろなタイプの色党異常がおこる、 電気刺激を加えることによって、それら錐体 細胞の低下していた機能が正常にまで回復す るからだと考えられる ${ }^{1)}$ 。色覚異常はこの 3 種
類の錐体細胞のいずれか、あるいは全部がそ の機能を発揮しないからだと考えられる。再 発は個人差があり、軽症で少ない回数で正常 化した人ほど完治しやすく、重症で多い回数 治療時間を費やした人程再検査、再治療を要 する。色盲表は不完全で正読できても治った ことにはならない、赫い色素を注射したとこ ろ正読できるようになった、又赦いガラスを とおして見ると、色盲患者でも正読できるこ とがある。色盲表が正読出来るまで色覚が向 上したと考える。

\section{おわりに}

良導絡治療の治効機序は今後の研究を待た ねばならないが、臨床的には色賞検査表が読 めることから、色党異常の患者のコンプレッ クス (理工科系入学、就職試験、縁談、自動 車免許取得など）に良導絡治療が貢献できる ものと考えられる。

\section{参考文献}

1）良導絡自律神経調整療法 中谷義雄 東京良導絡 研究所

2）良導絡自律神経調整療法〈基礎編〉日本鍼炎 良導絡医学会学術部

3）学校用色覚異常検査表 石原忍 侏半田屋商店

4）ひらがな色盲検査表 石原忍 侏半田屋商店

5）良導絡療法〈基礎と臨床〉後藤公哉 エンタプ

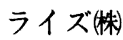

6）実用針炎治療表解 朱江云提 宋埼編 中医古籍 出版社

7）中医学基礎 上海中医学院編 神戸中医学研究会 燎原書店 